\title{
Strategies and stratagems of negotiation
}

\author{
Bianca Teodorescu \\ University of Craiova, 13 A. I. Cuza Street, Craiova, 200585, Romania \\ E-mail: daniamanolea@yahoo.com
}

\begin{abstract}
Negotiation is a dynamic process through two or more persons are discussing about some problems in order to reach a satisfactory agreement on common interest. The techniques of negotiation represent procedures, methods used by negotiators to approach the process. In this process, it is important to know how to handle the problems that appear in the negotiation in achieving the desired result. For winning the negotiation, the person who applies to the discussion needs to anticipate the steps that are taken by his partner and what kind of situation might call for his skills as a negotiator. The act of negotiation has four phases: preparation- identification of interest, debate- direct communication, proposal-suggestion in finding a solution and bargaining-obtaining a result. The negotiation is based on stratagems too. A stratagem is a scheme or a clever plot. Stratagems are persuasive strategies. All these elements must induce fear to the partner of negation in order to reach success. We can say that a negotiation is a complex communication based on a persuasive project.
\end{abstract}

Keywords: communication; negotiation; negotiation thinking; act of negotiation

\section{INTRODUCTION}

The negotiation is a way of thinking, a type of behavior or even a philosophy. Also, it can be seen like an art, science or technique. The art of negotiation belongs to a weak position; the art can not have any power. The negotiators need to cooperate in order to avoid the conflicts, for example to negotiate with the parents or the boss about the subjects of going somewhere or raising the salary. In mastering the art of negotiation, the influence and manipulation distinguish the behavior of the partners to make him to say "yes". In this case, the persuasion appears only when one of the partner of discussion master very well this technique. Good negotiating skills are essential for the running of a business (Kennedy, 2011; Dima, 2013). A negotiator needs to be able to negotiate with many different types of people in many different situations.

The technique of negotiation specifies that people are negotiating always. The base of the negotiation represents the trust of the partners. They search to cover some opinions that can betray their desired impressions resorting to various methods. Negotiation can be with or without intention. The structure of the negotiation is represented by two communicators that have social components; their goal is to maintain a good communication to achieve the persuasion plan. The purpose of this action is to accomplish new strategies, maneuvers or tricks and it is important to know that the freedom has restricted cultural and sociological boundaries. The negotiators can be also spokesmen because they are capable to earn the partner's trust and 
to impose his viewpoint about the subject that is discussed (Borowski, 2013; Avram \& Traistaru, 2014). In this case, the freedom of a negotiator is unlimited; it has the power to play with the limits of the other on his will. A negotiator is never obedient, he is searching always to lead the situation, even when he pass the word to someone else; this action is a maneuver, a control of negotiation. A person can be easy influenced by the action of the others. For a negotiation to be successful it has to depend on small disagreements; they can be seen as manipulative because this disagreements strengthens your position and it can weaken the others. But to resolve a major disagreement, the negotiators must think through to following points before they start negotiating: goals, trades, alternatives, relationships, expected outcomes, consequences, power and possible solutions.

\section{STRATEGIES AND STRATAGEMS}

Negotiation is a process composed by four phases: preparation, debate, proposal and bargaining. Preparation is the identification of interest's phase in which the negotiators are searching the solution of the problems. Here, we find three priorities:

- the first is based on obtaining the necessary needs in achieving the transaction

- the second represents important needs at the beginning of the transaction

- the last explain the needs that should be achieved and does not affect the final of transaction.

Debate is the part of the negotiation that is based on direct communication and is occupying most of the time. Here, the communication is represented by asking questions and finding answers and solutions. Without the proposal, all the process will be just a conversation. The proposals represent provisional suggestions where we find the solution.

Bargaining is the last part of negotiation and represents the result that is obtained as the last condition in which the offer is accepted (Vlăduţescu, 2013; Vlăduţescu, 2014; Frunză, 2014). For a negotiator to win the negotiation, he must follow some rules: to listen and to pay attention more to the negotiation than to speak without any sense. It is important that in a negotiation, the negotiator to have his last point of view about the discussed subject and to avoid negative presupposition that can bother the partner. The presentation must have positive messages with clean proofs in order to keep the understanding to a higher level; a negotiator's arguments has the power to act in a persuasive mode and to change the partner's opinion about the problems that they are discussing.

The strategy is the art that is used in finding all the available objectives in order to have success in a discussion and is composed in: direct and indirect strategies, cooperate and conflicting strategies. If the direct strategies are used when the negotiator is much stronger than his partner, the indirect ones indicates a weak negotiator with a stronger partner. In the conflicting strategies are existing negative and aggressive tactics of influence (warnings, direct threats), but in the cooperative strategies we find positive tactics of influence (promises, recommendations and rewards). The persuasive strategies control the maneuvers in the fundamental persuasive operation.

In a negotiation, the partners of the discussion sometimes apply to a double winning which means they are creating a stratagem. We can say that the stratagem represents everything in a negotiation act. Stratagems are persuasive strategy.

The first is the stratagem of hidden senses where the negotiators must insist on edification the accord of the agreement. Sometimes when the negotiators can not impose their point about 
the main problems, they have to insist through the stratagem of the hidden senses on inclusion the act of negotiation on the minor provisions of the understanding

The second, the stratagem of paraphrase follows to distort the content of negotiation in order to create a new form of the negotiator's interests (Sonderling, 2012).

Categorically terms are the third stratagem that is consisting in finding the weakness of the negotiation's partner in a manner to obtain new arguments to put in the discussion. In this case, the trick is to persuade people without be accused of lack of consistency; the result must be exploiting the partner's opinions to take some decisions.

The stratagem of questions consists in dominating the partner through questions. She is based on the idea that a question is a request in which the partner of negotiation is obligated to deny or to satisfy it. Here, it is important to know that the person, who is asking the questions, represents the leader. The asker controls the negotiation.

Another stratagem is represented by "yes, but..." This "yes, but..." stratagem promotes the word "no" like a modified "yes". The purpose of these words is to keep a balance in transactions and to create confusion between yes and no.

The stratagem of the sterile negotiation valorises the conversation. Sterile negotiation represents a negotiation that follows the conversation's rules with advantages and disadvantages. She seems to do not take serious the amicable discussion, but to focus on the engaged value of the next round of negotiation.

Stratagem of the small steps is based on obtaining a big result on processing small results. The negotiator must reach his purpose. When the partner of negotiation looses in minor problems, the negotiator reaches new steps in a big realization.

The last stratagem is about the control of the time, which consists in taking the decision about how we share the time in the negotiation's program (Gîrboveanu, 2005; Vlăduţescu \& Ciupercă, 2013). Negotiation is not paying attention to the conviction, instead she is relying more on persuasion; the difference between the conviction and persuasion is that the first is based on honest arguments and the second on lies. If the stratagems have moral projections in reaching the purposes, the maneuvers represent the punctual approaches in influence the elements of negotiation system (Sinaceur, Van Kleef, Neale, Adam, Haag, 20111; Grecu \& Păun, 2013).

Maneuvers in the negotiation process can be considerate constitutive modalities of the control stratagem. A type of maneuvers is represented by the time pressure, which allows interrupting the discussions to remember the limited time and to take the negotiation to a faster rhythm. Time-out maneuver provides ensures an ancestor on partner through damage the argument's order of the negotiation. Time-out leads to loose the consolidated position. In the negotiation process the most efficient maneuvers are those regarding the recipient partner. The simplest maneuvers of the recipient are represented by exploiting the first impulse. People are tented to act on their first impulse and because of that, they become more vulnerable. The maneuver exploits the vulnerability and the negotiation control "time out" consist in enforcing a break in the negotiation process when it is necessary. The allocated time can bring benefits to the negotiator that can obtain concession during the period of the negotiation. When the discussions of the negotiation are not favorable, the negotiator can exploit the maneuvers so the discussion can take more time. Without a proposal, all the negotiation process will be just a conversation. The proposal represents provisional suggestions that have the goal to reach an agreement (Tabără, 2012; Dima \& Vlăduţescu, 2012).

On the other side, the one who is the beneficiary of the allocated time in reaching his objectives; the negotiator can apply to the stratagem of the sterile negotiation. Therefore, in negotiation, we deal with negotiators liked to a relationship of negotiation. Other elements of 
the negotiation system are: context, situation or negotiation frame, feedback and feedforward, negotiation message and communication means.

In the negotiation system we find the negotiation process with his specifies interactions. Negotiation system has at base a negotiation relationship with the objective in reaching new performance (Lis \& Bajdor, 2013; Grabara \& Bosun, 2014; Modrak \& Bosun, 2014).

The difference between conviction communication and negotiation communication is the natural set of conditions for efficiency; if in the first we find honesty, solicitude, positive attitude, good will and good faith, in the second predominates seduction, lie, doubtful honesty, fiction and myth (Grabara, Kocun \& Kot, 2014). Before the start of the negotiation, the person who represents the negotiator is taking a self-presentation in which he is showing his openness, winning solidarity, mutual beneficial, empathy and positive attitude about the future discussion. For a negotiator to have success in the process of negotiation he has to know some important things that will generate fear like: difficult questions, making harder to answer, drying up - forgetting what to say, losing the attention of the partners and not capturing their interest in the first place (Raiffa, 1982; Buşu, 2013; Andresoi \& Buşu, 2013).

Collusion is a grouped maneuver achieved by the cooperation of two or more negotiators of an adverse team which target an opponent negotiator. The purpose of this maneuver is to make an ally between the two negotiators in manipulating the third person. This maneuver is composed in two parts: the first represents the secret understanding of two persons and the second the manipulation of the third person (Bazerman, Curhan, Moore, Valley, 2000; Colhon, 2013).

Role playing is another grouped maneuver which is consisting in integration of a group with the purpose to change the attitudes. It is based on an attitudinal modification. People have auto-confirmative and counter-attitudinal behaviors; for the auto-confirmative behaviors the role playing is in total agreement with attitudes, but for the counter-attitudinal behaviors the disagreement represents a specify features. The serious motivation in performing these types of behaviors is in making the obligation in a professional role, to act according to objective necessity or to please someone (Boncu, 2006; Traistaru, 2013; Siminică \& Traistaru, 2013).

The negotiation turns to rhetoric, to logic or to theory of argumentation, but sometimes she uses techniques of communication and manipulation. Notions like the offer, request, position, pretension, objection, compromise, concession, argument, transaction, argument and evidence can impose on the process of negotiation. Also, some elements of non-verbal communication (physiognomy, facial expressions, gestures, posture, and clothing) can have a major importance in the negotiation act.

Other elements of negotiation are represented by the culture and the power of the both negotiators. As knowledge of psychology, elements of tactics and strategy, pitfalls and rhetorical tricks can play a decisive role for small concession in receiving great benefits.

Negotiation is a concentrated form of interactive communication in which two or more parts reach to an agreement, solving a common problem or achieving a common goal.

\section{CONCLUSION}

Negotiation involves a mutually satisfactory agreement: win-win in order to establish mutual trust requiring honesty and integrity from both partners. In this situation, both negotiation's partners are working together to come up with a solution to suit everyone's best interests. The communication becomes less significant if the procedure of negotiation is increasing detail and specific. In this process of negotiation, you must know how to negotiate 
for your own, to claim terms and condition and to get out of tricky situations. Always look for the common ground and the area of mutual advantage.

\section{References}

[1] Kraus S. (2001). Strategic negotiation in multiagent environments. MIT Press.

[2] A. Borowski, International Letters of Social and Humanistic Sciences 14 (2014) 7-17.

[3] O. V. Buşu (2013). Social Image and Brand Image of Organization. Business Management Dynamics.

[4] Ş. Vlăduțescu (2013). Principle of the Irrepressible Emergence of the Message. Jokull.

[5] M. G. Mangra, E. A. Cotoc, A. Traistaru (2013). Sustainable Economic Development Through Environmental Management Systems Implementation. Journal.

[6] M. A. Neale, M. H. Bazerman (1991). Cognition and rationality in negotiation. New York: Free Press.

[7] H. Raiffa (1982). The art and science of negotiation. Harvard University Press.

[8] A. Borowski, International Letters of Social and Humanistic Sciences 11 (2014) 1-168.

[9] G. Kennedy (2010). Negotiation: An AZ Guide. Profile Books.

[10] Ştefan Vlăduţescu (2012). Networked Communication: the Communicational Emergence of Quasi-Controlable Social Networks. Analele Universităţii din Craiova. Comunicare. Media.

[11] Janusz Grabara, Michal Kolcun, Sebastian Kot (2014). The role of information systems in transport logistics. International.

[12] A. Țenescu (2009). Comunicare, sens, discurs. Craiova: Editura Universitaria.

[13] Paula Bajdor, Iwona Grabara, (2014). The Role of Information System Flows in Fulfilling Customers' Individual Orders. Journal.

[14] I. C. Dima, Ş. Vlăduţescu (2012). Persuasion elements used in logistical negotiation: Persuasive logistical negotiation. Saarbrucken: LAP Lambert Academic Publishing.

[15] A. Borowski, International Letters of Social and Humanistic Sciences 14 (2014) 33-41.

[16] Sandu Frunză (2014). Advertising and Administration under the Pressure of Ethics. Les Arcs: Editions de la Suers.

[17] Vladimir Modrak, Petre Bosun, International Letters of Social and Humanistic Sciences 14 (2014) 66-72.

[18] V. Tabără (2012). Dezvoltarea capacităţii administrative. Bucureşti: Editura CH Beck.

[19] Ştefan Vlăduțescu, American International Journal of Contemporary Research 3(10) (2013).

[20] Marian Siminică, Autrelia Traistaru (2013). Self-Directed Learning in Economic Education. International.

[21] Ş. Boncu (2006). Negocierea şi medierea. Perspective psihologice. Iaşi, Institutul European. 
[22] A. Borowski, International Letters of Social and Humanistic Sciences 4 (2013) 70-74.

[23] S.. Prutianu (2000). Manual de comunicare și negociere în afaceri: Negocierea. Polirom.

[24] Ştefan Vlăduţescu (2014). Eight Computational-Communicative Operations of Building Information. Mitteilungen Klosterneuburg.

[25] A. Tenescu, Annales Universitatis Apulensis. Series Philologica 12/(2) (2011) 235-250.

[26] E. A. Cotoc, A. Traistaru, A. Stoica, (2013). Systems of Environmental Management. European.

[27] Ş. Vlăduţescu, E. M. Ciupercă (2013). Next Flood Level of Communication: Social Networks. Aachen: Shaker Verlag.

[28] L. L. Putnam (Ed.). (1992). Communication and negotiation. Newbury Park, CA: Sage.

[29] A. Borowski, International Letters of Social and Humanistic Sciences 3 (2013) 69-74.

[30] Marioara Avram, Aurelia Traistaru, International Letters of Social and Humanistic Sciences 13 (2014) 79-88.

[31] S. R. Gîrboveanu (2005). Comunicare şi negociere în afaceri. Craiova: Universitaria.

[32] L. L. Thompson, J. Wang, B. C. Gunia, Annual review of psychology 61 (2010) 491-515.

[33] Ştefan Vlăduţescu (2013). The communication membranes. European.

[34] Janusz Grabara, Petre Bosun, International Letters of Social and Humanistic Sciences 14 (2014) 59-65.

[35] L. M. Grecu, M. G. Păun (2013). Journalistic Construction of National Identity of Romanians in 2006. European.

[36] A. Borowski, International Letters of Social and Humanistic Sciences 4 (2013) 70-74.

[37] C. E. Andresoi, O. V. Buşu, (2013). Social Image Concept. Business Management Dynamics.

[38] S. Ting-Toomey, Theory and intercultural communication (1988) 47-92.

[39] Ştefan Vlăduțescu (2013). What Kind of Communication Is Philosophy? Jokull.

[40] Colhon, M. (2013). Automatic Lexical Alignment between Syntactically Weak Related Languages. Application for English and Romanian. In Computational Collective Intelligence. Technologies and Applications (pp. 266-275). Springer Berlin Heidelberg.

[41] M. H. Bazerman, J. R. Curhan, D. A. Moore, K. L. Valley, Annual review of psychology 51(1) (2000) 279-314.

[42] M. Sinaceur, G. A. Van Kleef, M. A. Neale, H. Adam, C. Haag, Journal of Applied Psychology 96(5) (2011) 1018.

[43] Aurelia Traistaru (2013). Consolidation of the green marketing profile in current austerity period. Jokull.

[44] Ştefan Vlăduţescu (2013). Message as Fundamental Discursive Commitment of Communication. Journal. 
[45] T. Lis, Paula Bajdor (2013). Sales Logistics as a Model Used by Companies Fulfilling Individual Customer's Needs. In: Challenges in Contemporary Management. Monograph. Scientific Editors Anna Lemańska-Majdzik, Piotr Tomski, Sekcja Wydaw. WZ PCzęst, Czestochowa.

[46] I. Iancu, N. Constantinescu, M. Colhon, International Journal of Computers Communications \& Control 4(5) (2010) 525-531.

[47] A. Borowski, International Letters of Socia and Humanistic Sciences 2 (2014) 110-121.

[48] A. Borowski, International Letters of Social and Humanistic Sciences 3 (2013) 46-53.

[49] Rajesh K. Yadav, Nishant Dabhade, International Letters of Social and Humanistic Sciences 4 (2013) 49-69.

[50] Jacek Tittenbrun, International Letters of Social and Humanistic Sciences 11 (2013) 10-34.

[51] Ștefan Vlăduțescu, International Letters of Social and Humanistic Sciences 10(2) (2014) 100-106.

[52] Ştefan Vlăduţescu (2013). Three Diachronic Paradigms of Communication. International.

[53] Cerasela Vintilescu (2011). Potenţialul turistic al judeţului Gorj. Craiova: Editura Legis.

[54] M. Colhon, Computer Science and Information Systems/ComSIS 9(3) (2012) 1231-1247.

[55] M. Colhon, N. Tandareanu, Annals of the University of Craiova-Mathematics and Computer Science Series 37(1) (2010) 55-70.

[56] Ştefan Vlăduţescu, International Letters of Social and Humanistic Sciences 14 (2014) 73-81.

[57] S. Sonderling, Communicatio 38(1) (2012) 64-83.

[58] Ioan Constantin Dima (2013). Organisational strategies - a systemic approach - on the example of the automotive industry. Saarbrucken: LAP Lambert Academic Publishing.

[59] Ș. Vlăduțescu, International Letters of Social and Humanistic Sciences 13 (2014) 71-78.

[60] C. Vintilescu, International Letters of Social and Humanistic Sciences 13 (2014) 58-63. 